Review article

DOI: http://doi.org/10.20914/2310-1202-2017-1-134-137

\title{
An overview on applications of guar gum in food systems to modify structural properties
}

\author{
Biljana B. Popova ${ }^{1}$ \\ Vesna K. Hristova 1 \\ M. Ayaz Ahmad 2 \\ M. Ali Shariati \\ mayaz.alig@gmail.com
}

${ }^{\overline{1}}$ University St. Kliment Ohridski, P. O. Box 7000, Bitola, Republic of Macedonia

${ }^{2}$ University of Tabuk P.O. Box 71491, Saudi Arabia

${ }^{3}$ All Russian Research Institute of Phytopathology, Moscow Region, Russia

Summary. Polysaccharides define as complex polymers composed of units interlinked with glycosidic bonds originated naturally. Polysaccharides are categorizing in several groups and among them, Gums are those with critical roles in food systems. Guar Gum is imparting softness, emulsification, stabilizing via its addition to formulas. This Gum is a fast soluble in cold water and can be active in a wide range of $\mathrm{pH}$. The aim of this overview is giving an initial concept about guar gum and then convey to an introduction of its applications in food industries.

Keywords: gallactomannan, natural polysaccharide, guar gum, rheology, food structure, polysaccharide

\section{Introduction}

Guar Gum or guaran is extracting from endosperm of Cyamopsis tetragonolobus (figure 1) and C. psoraloides [1]. Guar plant belongs to family Fabaceae or $\mathrm{Le}$ guminaceae. Common name, is guar, from sankrist word "go" or "gav". Guar bean contains a large endosperm rich in galactomannan, a gel forming agent in water. As depicting in figure 1 Guar gum is composed of chain $(1 \rightarrow 4)$ - linked $\beta$-D mannopyranosyl units substituted at O- 6 by single-unit side-chains of $\alpha$-Dgalactopyranose (figure 3) [2]. The germ and hull of the guar seeds are called Guar meal, which is rich in protein. Figure 2 depicts different part of Guar seed.

There are some parameters effects on characteristics of Guar gum such as particle size, temperature [4].

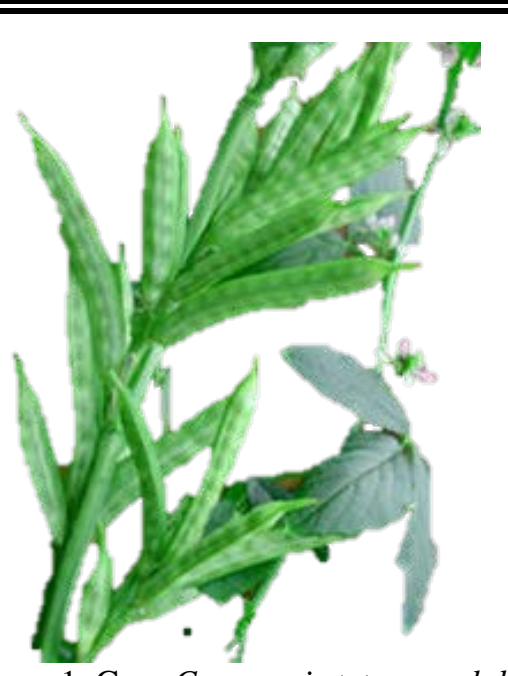

Figure 1. Guar Cyamopsis tetragonoloba
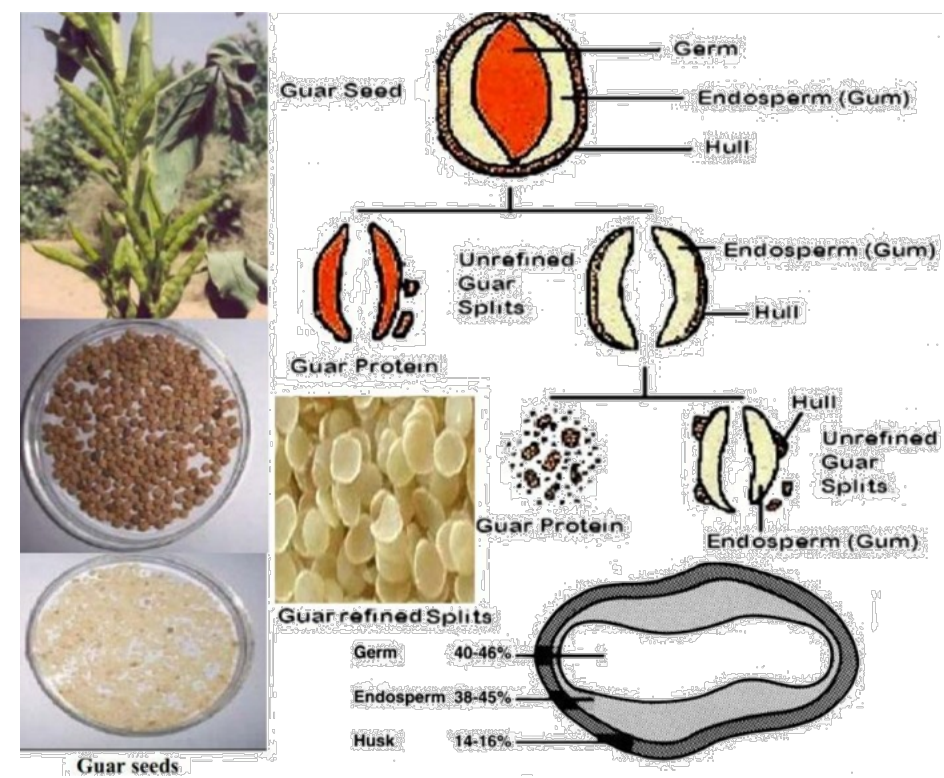

Figure 2. Schematic of different parts of Guar seed

Для цитирования

Biljana B. Popova, Vesna K. Hristova, M. Ayaz Ahmadc, M. Ali Shariati An overview on applications of guar gum in food systems to modify structural properties // Вестник ВГУИТ. 2017. Т. 79. № 1. С. 134-137. doi:10.20914/2310-1202-2017-1-134-137
For citation

Biljana B. Popova, Vesna K. Hristova, M. Ayaz Ahmadc, M. Ali Shariati An overview on applications of guar gum in food systems to modify structural properties. Vestnik VGUIT [Proceedings of VSUET]. 2017. Vol. 79. no. 1. pp. 134-137. (in Russian). doi:10.20914/2310-1202-2017-1-134-137 


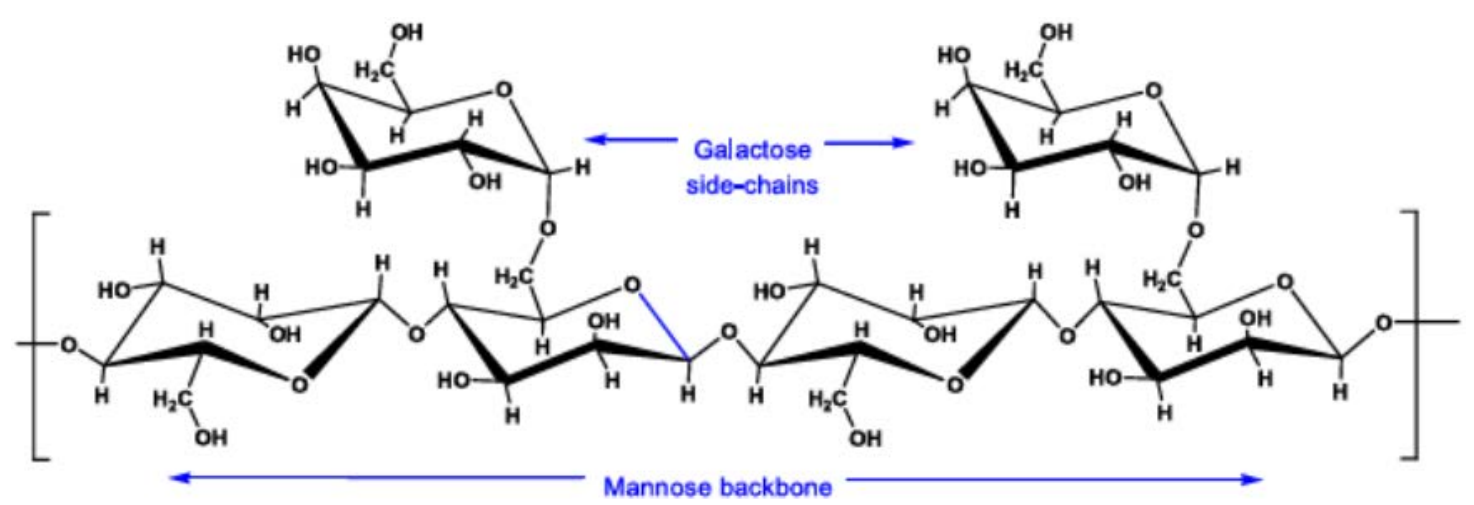

Figure 3. The Schematic of chemical structure of Guar Gum

\section{Results and discussions}

Increase the molecular weight and concertation increases the non-Newtonian behavior of guar solutions [5, 6]. It is native in India, Pakistan, united states and some parts of Sudan are the originality of Guar plant.

Guar is a plant exudate and can participate in viscosity and gelling process characteristics. A distinctive properties of polysaccharides in performance of natural systems are their hydrogen bonding potentials which makes them appropriate in useful services.

Dietary polysaccharides refer to a group with inert structure, mainly non soluble, by which some rheological and sensory characteristic of a food system modifies. Remained polysaccharides can drive compactness thickening quality etc. First time, guar found as source of gum in 1945 and started to become a global prominence crop [7].

Mostly the application of guar gum can summarize as below:

1. Drying and preserving of pod for future [8, 9].

2. With respect to be a high protein source, it uses as Mammals' feeding [10].

3. To cure night blindness, smallpox, enlarged liver, head swelling [11].

Rheological properties of Guar gum could be arising from random coil polymers of this gum in solutions [12, 13]. Gum behaves thixotropic and immediately forms a high viscous solution in cold water [14].

In addition, stability of guar gum in acidic condition is reasonable the lowest possible $\mathrm{pH}$ found to be stable is 2 at $25{ }^{\circ} \mathrm{C}$ [9]. Indeed, guar gum is a kind with a wide range of food applications such as ice cream, meat and dairy products. Some roles of Guar which has found suitable in food systems are reduction of chewiness, prevention of ice growth, enhancing organoleptic and sensory properties [10]. High viscosity makes guar suitable in case of bakery products in which moisture retention influenced by while in frozen foods it prevents synersis [15].

Ice cream, a food product with superiority of being normal healthy, easy digestibility and a good source of Vits [16] indicates a pseudo plastic behavior. [17].

Certainly, guar gum plays in improving of ice cream in both consistency and viscosity. It also aids the stabilization while changing in flavor [18, 19].

In cold water, guar gum swells and its technical degree depends on the rate of thickening and final viscosity. Guar gum is commonly considerable as a locust bean gum replacer. The main difference arises from their interaction to viscosity; Guar dissolves in cold water, whereas locust bean gum needs cooking for reaching to Max of viscosity [7].

Overall, guar gum gives a time, concentration and temperature dependent viscosity. up to a $0.5 \%$ concertation of guar gum we can see a linear Newtonian like behavior while in more concentrations pseudo plastic flow gives a concept of molecular interactions [20, 21].

The amount of $0.1-1.15 \%$ of Guar gum to finished cake creates better icing and frosting along with more moisture retention during shelf life. Guar gum causes that bakery products have a more integrate structure as well as yields to an easy slicing texture with no crumbling. Salad dressing also can be formulated by addition of guar gum owing to its high binding capacity. Guar gum also can prevent migration of food constituents mainly fat, controlling of WHC [7].

Guar can increase the viscosity of the aquatic phases followed by reduction in separation rate of W/O phases [22]. Since beverage is processing under cold conditions therefore solubility of guar in cold water is a point which along with resistance at low $\mathrm{pH}$ conditions consider a precedence. In order of beverage a $0.1-0.15 \%$ of weight can be sued [7]. Table 1 has summarized recent studies on the guar applications in food industries. 
Application of guar in food industries

\begin{tabular}{|c|c|c|}
\hline The type of food & Application of Guar & References \\
\hline Beverage & control viscosity as well as to reduce calories & 23 \\
\hline Pet food & As dietary fiber and is safe for a wide range of animal & 24 \\
\hline $\begin{array}{c}\text { salad dressings, sauces, relishes, } \\
\text { ketchups and canned soup }\end{array}$ & Control glazing. Blooming and moisture retention & 25 \\
\hline frozen food and meat products & Binding properties & 26 \\
\hline Ice cream & Enhance structural characteristics and reduction of crystal growth & 26,27 \\
\hline Low fat yogurt & Reduction of synersis & 26 \\
\hline Bakery products & dough yield and inhibit synersis & 28 \\
\hline Dairy products & thickener & 29 \\
\hline chapati & Create softness & 30 \\
\hline Fried products & Reduction of oil uptake & 31 \\
\hline cake & Impart replacer & 32 \\
\hline Sausage & Enhancing of consistency & 33 \\
\hline Tomato ketchup & & 34 \\
\hline
\end{tabular}

\section{Conclusion}

Based on the current overview, it can be said that guar gum considers as a source of human nutrition. This hydrocolloid is one of the practical gums in food industries and systems which has been used historically as food, additive. It is also a supplement additive to enhance the quality of food materials. The following study is still needed to discover the novelty of this gum for various sections.

\section{REFERENCES}

1 Whistler, R. L. and Dabiel, J. R. (1985). Carbohydrates in food chemistry (O. R. Fennema, eds). Marcel Dekker, Inc., New York Basel, pp, 69-137.

2 Raymond C. RoweSian C. Owen Paul J. Sheskey, Handbook of Pharmaceutical Excipients., and 6 ${ }^{\text {th }}$ Edition, 2009, 369.

3 Dea, I. C. M., Morris, E. R., Rees, D. A., Welsh, E. J, Barnes, H. A., \& Price, J. (1977). Associations of like and unlike polysaccharides: mechanism and specificity in galactomannans, interacting bacterial polysaccharides, and related systems. Carbohydrate Research, 57, 249-272.

4 Meir, G., Meer, W. A. and Gurd, T. (1973). Gum tragacanth, In: Industrial Gums, polysaccharides and their derivatives (R. L. Whistler and J. N. Be Miller, eds). Academic Press. New York, pp. 289-299.

5 Elfak A.M., Pass G., Philips G.O., Molley R.G., 1977. Journal of Science, Food \& Agriculture, 28 (10), 895

6 McCleary B.V., Clark a. H., Dea I.C.M., Rees D.A., 1981. „The fine structure of carob and guar galactoman-

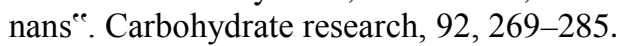

7 Hymowitiz, T. and Matlock, R. S. (1963). Guar in the United State. Okla. Exp. Stn. Bull. 611:1-34.

8 Wiser, C. L. (1955). The food of handu village of north India. Ann. Mobot Cand. 42:303-412.

9 Hupricar, S. V. and Sohonie, C. (1961). Haemaglutinins in India Pulses: Part 1. Detection of haemaglutinating activity. J. Sci. Ind. Res. Sect. 20:52-85.

10 Murry, J. (1908). The commercial products of India, In: Guar Agronomy, Production, Industrial use and Nutrition (R. L. Whistler and T. Hymowitiz, eds.) Purdue University Press, West Lafayette, India.

11 Chopra, R. N.; Nayer, S. L. and Chopra, I. C. (1956). Glossary of Indian medicinal plants, Panchi, Catholic Press.

12 Robinson G., Ross-Murphy S.B., Morris E.R., 1982. „Viscosity-molecular weight relationships, intrinsic chain flexibility and dynamic solution properties of guar galactomannan". Carbohydrate Polymers, 107 (1), 17-32.

13 Morris, E. R., Rees, D. A., Young, G., Walkinshaw, M. D., \& Darke, A. (1977). Order - disorder transition for a bacterial polysaccharide in solution. A role for polysaccharide conformation in recognition between Xanthomonas pathogen and its plant host. Journal of Molecular Biology, 110, 1-16.

14 Wang, F. 2001. Study of polysaccharide-polysaccharide interaction in solution. MS thesis, University of Arkansas, Fayetteville, Arkansas.

15 Whistler R.L., Bemiller J.N., Paschall E.F., (eds) 1984. Starch : Chemistry and Technology, 2nd edn, Academic Press, New York.

16 Varnam A.H., Sutherland J.P. Milk and Milk Products: Technology, Chemistry and Microbiology. London, Chapman and Hall. 1994.

17 Tantry J.S. and Nagarsenker M.S. (2001). Rheological study of guar gum. Journal of Food Hydrocolloids, 21(15):7790-795.

18 Koxholt, M.M.R., Eisenmann B. and Hinrichs, J. (2001). Effect of the fat globule sizes on the meltdown of ice cream. J. Dairy Sci., 84: 31-7.

19 Prindiville, E.A., Marshall R.T. and Heymann, H. (2000). Effect of milk fat, cocoa butter, and whey protein fat replacers on the sensory properties of low fat and nonfat chocolate ice cream. J. Dairy Sci., 83: 2216-23. 


\section{Becтник BTYYHTI/Proceedings of VSUET, TI. 79, № 1, 2017}

20 Glicksman (1979). Gelling Hydrocolloids in Food Product Application. Polysaccharides in Food. J. M. JMV Blanshard. Boston, Butterworths.

21 Charm, S. (1960). Viscosity of non-Newtonian food materials. Food Res. 25:351-362.

22 Eu.rreil, J. R. (1958). Pickles and sauces, J. Food Manul. 3 3:10-17.

23 H. Takahashi, S.I. Yang, M. Fujiki, M. Kim, T. Yamamoto, N.A. Greenberg, Int. J. Toxicol. 13 (1994) 273-278.

24W.A. Carlson, E.M. Ziegenfuss, J.D. Overton, Food Technol. 16 (1962) 50-54.

25W.A. Carlson, E.M. Ziegenfuss, Food Technol. 19 (1965) 64-68.

26 C.S. Brennan, C.M. Tudorica, Int. J. Food Sci. Technol. 43 (2008) 824-833.

27 R.L. Sutton, J. Wilcox, J. Food Sci. 63 (1998) 104-107

28T. Miyazawa, Carbohydr. Res. 341 (2006) 870-877.

29 J.B. Klis, Food Process. Mark. 27 (1966) 58-59.

30 S.K. Ghodke, Int. J. Food Eng. 5 (3) (2009), Article 7.

31 B.K. Sakhale, J.B. Badgujar, V.D. Pawar, S.L. Sananse, J. Food Sci. Technol. 48(6) (2011) 769-772.

32 F. Zambrano, P. Despinoy, R.C.S.C. Ormenese, E.V. Faria, Int. J. Food Sci. Technol. 39 (2004) 959-966.

33 S. Andres, N. Zaritzky, A. Califano, Int. J. Food Sci. Technol. 41 (2006) 954-961.

34 H.S. Gujral, A. Sharma, N. Singh, Int. J. Food Prop. 5 (2002) 179-191.

\section{INFORMATION ABOUT AUTHORS}

Biljana B. Popova Veterinary Faculty, University St. Kliment Ohridski, P. O. Box 7000, Bitola, Republic of Macedonia Vesna K. Hristova Faculty of Biotechnical Sciences, University St. Kliment Ohridski, P. O. Box 7000, Bitola, Republic of Macedonia

M. Ayaz Ahmad Physics Department, Faculty of Science, University of Tabuk, P.O. Box 71491, Saudi Arabia, mayaz.alig@gmail.com

M. Ali Shariati Research Department, LLC “Science \& Education”, All Russian Research Institute of Phytopathology, Moscow Region, Russia

\section{CONTRIBUTION}

Biljana B. Popova wrote the manuscript, correct it before filing in editing

Vesna K. Hristova review of the literature on an investigated problem

M. Ayaz Ahmad consultation during the study

M. Ali Shariati is responsible for plagiarism

\section{CONFLICT OF INTEREST}

The authors declare no conflict of interest.

RECEIVED 2.7.2017

ACCEPTED 2.1.2017 